Por Mares Nunca Dantes Navegados: Estudos para a Inclusão da População de Baixa Renda na Sociedade da Informação

Orientador: Prof. Associado Dr. Marcelo Tramontano 


\section{Por mares nunca dantes navegados: estudos para a inclusão da população de baixa renda na sociedade da informação}

\section{Nilton Trevisan}

Orientador: Prof. Associado Dr. Marcelo Tramontano

Dissertação de mestrado apresentada à Escola de Engenharia de São Carlos da Universidade de São Paulo, como parte dos requisitos para a obtenção do Título de Mestre em Arquitetura e Urbanismo Tecnologia do Ambiente Construído.

São Carlos, 2005. 


\section{Agradecimentos}

Agradeço ao meu Pai Olzeno Trevisan, a minha Mãe Ildaci Batista Trevisan e a minha família por sempre estarem ao meu lado, aos amigos do Nomads.usp pelas conversas e apoio, em especial aos pesquisadores: Arq. Ângela Pereira Campos de Pinho, Arq. Clarissa Ribeiro, Ms. Denise Mônaco dos Santos, Arq. Edson Salerno Junior, Arq. Carlos Augusto Joly Requena, Arq. Mayara Dias, Arq. Marcos Marchetti Arq. Renata La Rocca, Arq. Cynthia Nojimoto, Arq. Tatiana Sakurai, as pesquisadoras Patrícia Junqueira, Denise Melo e Fernanda Borba, as Professoras Dra. Anja Pratschke e Dra. Varlete Benevente, e a todas as pessoas que me ajudaram na realização deste trabalho. Finalmente serei eternamente grato ao Professor Dr. Marcelo Tramontano por tudo o que me ensinou.

Também sou grato ao apoio da Capes - Coordenação de Aperfeiçoamento de Pessoal de Nível Superior- pela ajuda financeira sem a qual esta pesquisa seria seriamente prejudicada. 


\section{Resumo}

O foco principal desta pesquisa foi a análise de experiências que utilizam as atuais tecnologias de informação e comunicação, em especial a internet, de modo a promover a inclusão digital de comunidades menos favorecidas no Brasil e no mundo. Foram abordadas experiências em comunidades espacialmente referenciadas, ou seja, comunidades concretas que se comunicam também no espaço virtual. Pretendeu-se analisar o modelo de inclusão digital através dos chamados telecentros, utilizados amplamente em vários países, e de algumas experiências significativas que ultrapassem este modelo. Buscou-se, além disso, compreender os mecanismos da chamada "inclusão digital", sua ligação com a chamada inclusão social e meios para promovê-la, como por exemplo, o uso de software livre e desenvolvimento de tecnologias mais simples e acessíveis.

Palavras chaves: Inclusão digital; telecentros; redes digitais; software livre; tecnologias da informação e comunicação.
The main focus of this research was the analysis of experiences that use the current technologies of information and communication, in special, the Internet, in order to promote the digital inclusion in communities in Brazil and all over the world. Concrete communities that communicate in the virtual space will be referred. It is intended to analyze the model of the digital inclusion through telecenters, widely used in some countries, and of some significant experiences that exceed this model. Beyond, the research tries to understand the mechanisms of "digital inclusion", its links with social inclusion and the ways to promote it, for example, the use of free software and the development of simpler and accessible technologies.

Key words: Digital inclusion; telecenter; digital nets; free software; information and communication technologies. 
I ntrodução

Capítulo 1- Princípios da I nclusão Digital

1.1 A Rede Mundial de Computadores

16

1.2 Inclusão Digital

25

1.3 A Formação de uma Nova Sociedade

28

1.4 Governo Eletrônico

34

1.5 Software Livre

36

Capítulo 2 - Em Torno dos Telecentros

2.1 Telecentros

41

2.2 Descrição e Análise das Experiências

47

2.2.1 Experiências Nacionais

48

2.2.2 Experiências internacionais

79

2.3 Análise dos Resultados 
Capítulo 3 - Além dos Telecentros

101

3.1 Descrição e Análise das Experiências

102

3.1.1 Experiências Nacionais

103

3.1.2 Experiências internacionais

113

3.2 Análise dos Resultados

131

Conclusões

136

Referências bibliográficas

Bibliografia consultada

I conografia 
"Três datas fundadoras caracterizam a Renascença européia: 1454, 1492, 1517.

Três nomes a pontuam: Gutemberg, Colombo, Lutero.

Três invenções a resumem: a imprensa, a América, a Reforma.

Não é uma nova Renascença que se prepara, um renascimento mundial?

Como há mais de cinco séculos, assistimos à invenção quase simultânea de uma nova imprensa, uma nova América e uma nova Reforma.

A nova imprensa é o digital e o virtual.

A nova América é o ciberespaço e o novo mundo da abstração financeira e tecnológica.

A nova Reforma emerge. É a do bem comum mundial."

Philippe Quéau, (2000). 
Com o advento da chamada era da informação ${ }^{1}$, pensadores como Manuel Castells, Eric Hobsbawn, Philippe Quéau, Pierre Lévy, Nicolas Negroponte, William J. Mitchell e Jean Baudrillard discutem as mudanças econômicas, produtivas, sociais, institucionais e culturais, que as chamadas novas Tecnologias da Informação e da Comunicação, as TICs ${ }^{2}$ - também denominadas novas mídias ou, simplesmente, novas tecnologias - estão impondo ao mundo, como a convergência tecnológica e a informatização das sociedades contemporâneas. Estas transformações estão centradas no fluxo das informações, e, consequentemente, na geração de conhecimento, e podem ser percebidas em grande parte dos países do mundo, com implicações diversas para as suas populações. De seu uso decorrem novas formas de sociabilidade, como a possibilidade crescente de comunicar-se e obterem-se informações a qualquer hora e qualquer lugar ${ }^{3}$. As consequências que o uso destas novas mídias acarreta no dia a dia dos indivíduos e grupos sociais ainda estão sendo mensuradas, mas análises preliminares - em grande parte feitas pelos pensadores citados anteriormente - indicam que as TICs possuem forte tendência a melhorar a qualidade de vida das comunidades onde estas estão sendo utilizadas. Entretanto, atualmente, apenas uma parcela da população mundial, menos de 1/6 de acordo com Castells (2003 p. 174), tem acesso à maioria destas tecnologias. Os demais são os chamados excluídos digitais. A preocupação crescente com o tema justifica-se plenamente. Como lembra Sorj,

A exclusão digital possui forte correlação com as outras formas de desigualdade social, e, em geral, as taxas mais altas de exclusão digital encontram-se nos setores de menor renda. A desigualdade social no campo das comunicações, na sociedade moderna de consumo de massas, não se expressa somente no acesso ao bem material - rádio, telefone, televisão, internet -, mas também na capacidade do usuário

\footnotetext{
1 "Termo usado pelo sociólogo espanhol Manuel Castells, professor da Universidade de Berkeley - USA. Sua trilogia A Era da Informação: Economia, Sociedade e Cultura, analisa em profundidade as mudanças paradigmáticas dos últimos anos." (Tramontano et al. 2004a, p. 3)

2 "Termo [...] correntemente utilizado para definir uma vasta gama de serviços, aplicações e tecnologias, utilizando vários tipos de hardware e software, servindo-se frequentemente das redes de telecomunicações. As TIC incluem serviços de telecomunicações bem conhecidos tais como a telefonia fixa, a telefonia móvel e o fax. Os serviços de telecomunicações associados ao hardware e ao software constituem a base de outros serviços, incluindo o correio eletrônico, a transferência de arquivos de um computador para outro, e, sobretudo, a internet que potencialmente permite que todos os computadores estejam ligados entre si fornecendo assim um acesso a fontes de conhecimento e de informação armazenadas nos sistemas informáticos de todo o mundo. As aplicações incluem a videoconferência, o teletrabalho, o ensino à distância, sistemas de gestão da informação, inventários; as tecnologias são múltiplas, desde as mais "velhas" como a rádio e a televisão às mais novas como as comunicaçóes móveis celulares. [...] A importância das TIC não consiste nas tecnologias como tal, mas no fato de que estas permitem o acesso ao conhecimento, à informação e à comunicação: elementos cada vez mais importantes nas interações econômicas e sociais de hoje". (COMUNICAÇÃO DA COMISSÃO AO CONSELHO E AO PARLAMENTO EUROPEU, 2001, p. 3.). E importante ressaltar que este é um termo deficiente pois não engloba os atores envolvidos, mas atualmente é o termo mais utilizado.

${ }^{3}$ Inclusive também em lugares remotos do planeta através da conexão com satélites.
} 
de retirar, a partir de sua capacitação intelectual e profissional, o máximo proveito das potencialidades oferecidas por cada instrumento de comunicação e informação. (SORJ, 2003, p. 59).

Este grave problema social motiva várias discussões sobre como atuar para disponibilizar para as populações de menor renda o acesso as TICs, promovendo assim a chamada inclusão digital, Assumpção (2001, p. 26 e 27) afirma que

Todos os discursos e iniciativas parecem concordar que a inclusão digital é uma forma de inclusão social. Ou seja, o acesso às Tecnologias de Informação e Comunicação contribui com o combate à desigualdade, seja através das maiores possibilidades de desenvolvimento econômico, seja pela inserção na sociedade do conhecimento. (...) As TICs são os principais instrumentos da aceleração da vida globalizada e frenética na qual estamos imersos, são também uma das grandes esperanças de libertar energias e processos criativos, de criar e compartilhar conhecimentos, de enfrentar as carências educacionais e informacionais. Este potencial tem sido amplamente reconhecido em vários espaços governamentais, multilaterais, empresariais e institucionais. (...) A "brecha digital" ameaça exacerbar as desigualdades sociais e econômicas existentes entre países e comunidades, sendo que os custos potenciais da inação estão maiores do que nunca.

O objetivo desta pesquisa é compreender mecanismos da exclusão digital e sua relação com a exclusão social, e quais os meios possíveis para combatê-la, para que se incluam digitalmente as comunidades menos favorecidas, no Brasil e no mundo. Neste intuito, a pesquisa irá analisar experiências nacionais e internacionais que utilizam as atuais Tecnologias de Informação e Comunicação, em especial a internet, para promover sistemas informatizados comunitários no sentido de combater a exclusão digital. Serão abordados somente exemplos relacionados a comunidades concretas espacialmente referenciadas. Será analisado o modelo de inclusão digital nucleados em torno dos chamados telecentros, utilizados amplamente em muitos países do mundo, e de algumas experiências significativas que ultrapassam este modelo, utilizando-se das tecnologias de informação e comunicação de modo mais abrangente.

Além do enfoque na área das ciências sociais, esse trabalho contempla aspectos que envolvem a arquitetura, como a qualificação do espaço físico e virtual, que podem não estar presentes em outros estudos correlatos. Um dos papéis do arquiteto, ao enfrentar a problemática da exclusão digital, seria o de contribuir para o enriquecimento do tema, através da ótica da arquitetura. É importante que o arquiteto também perceba como estas novas mídias modificam os comportamentos sociais em relação às cidades e os 
espaços coletivos e individuais; que estão ocorrendo mudanças significativas nos atuais modos de vida, e que estas mudanças certamente estão modificando os espaços onde vivemos.

Os seguintes pontos não serão abordados profundamente nesta pesquisa: o surgimento das comunidades unicamente virtuais e sua influência na sociedade; a ascensão das chamadas cidades digitais, que existem somente no espaço virtual, mas possuem relações diretas com o que pode-se chamar de cidade concreta; a criação de interfaces colaborativas para comunidades que se localizam em espaços concretos, e com problemas sociais; e, por último, como as novas mídias estão modificando os espaços domésticos.

Todas estas questões são absolutamente pertinentes, mas nessa dissertação não serão analisadas em profundidade, devido aos limites do recorte temático da pesquisa. Nesse sentido, essa pesquisa se propõe a ser um subsídio para pesquisas futuras sobre estes temas, para que, a partir desta análise, outros trabalhos contribuam para a promoção da inclusão digital. Como a presente análise foi realizada dentro do contexto de diferentes pesquisas desenvolvidas pelo Nomads.usp ${ }^{4}$ Núcleo de Estudos sobre Habitação e Modos de Vida, da Universidade de São Paulo, inseridas na linha Habitação e Virtualidade, este trabalho fornece subsídios também para outras pesquisas do Nomads.usp e dialoga com pesquisas em nível de Políticas Públicas, Doutorado, Mestrado e Iniciação Científica.

Já há alguns anos, o Nomads.usp busca compreender a evolução atual da vida cotidiana da população urbanizada, buscando embasar o projeto de espaços adequados ao tempo presente. O Núcleo parte da constatação de que, tanto a comunicação interpessoal como o acesso a fontes de informação vêem-se cada vez mais mediados por dispositivos eletro-eletrônicos de transmissão à distância, e que a relação entre esses dispositivos e seus usuários tem se apoiado em graus crescentes de interatividade. A essa tendência vem somar-se uma outra: a de que o custo final de muitos desses dispositivos tem diminuído, a ponto de permitir sua disseminação entre grupos domésticos de menor renda, como ocorreu com os televisores, já há algumas décadas, e, bem mais recentemente, com os

${ }^{4}$ O Nomads.usp Núcleo de Estudos sobre Habitação e Modos de Vida, da Universidade de São Paulo, ligado ao Departamento de Arquitetura e Urbanismo da Escola de Engenharia de São Carlos, propõe-se a repensar o desenho dos espaços da habitação contemporânea, considerando as transformações ocorridas nos grupos familiares a partir da sociedade industrial, suas atuais tendências comportamentais, assim como sua relação com o uso de novas mídias. Isto inclui o redesenho de seu mobiliário e a revisão de seu repertório construtivo, priorizando preocupações de cunho ambiental, através de reflexões teóricas e de realizações experimentais.

O Nomads.usp possui as seguintes linhas de pesquisa:

Habitação Metropolitana: Habitação contemporânea, Apartamentos, Flats, Condomínios horizontais, Habitação social.

Habitação e Ambiente: Design contemporâneo, Materiais de baixo impacto ambiental.

Habitação e Virtualidade: Novas mídias e alterações do espaço doméstico, Ambientes virtuais.

Para maiores informações sobre as pesquisas do grupo visite o site http://www.eesc.usp.br/nomads. 
aparelhos telefônicos móveis - os celulares. Com as suas pesquisas, o Núcleo espera estar contribuindo para uma melhor compreensão destas questões, identificando os possíveis problemas, procurando propor soluções inovadoras e abrindo novas possibilidades de atuação para os profissionais arquitetos.

Uma destas pesquisas que está diretamente relacionada com o tema desta dissertação, alimentando-se da mesma, é o projeto Comunidades_online ${ }^{5}$, pesquisa de políticas públicas financiada pela Fapesp. Trata-se de um projeto interdisciplinar, cuja equipe envolve, além do Nomads.usp, pesquisadores de outras unidades da Universidade de São Paulo, como o Laboratório de Sistemas Integráveis-USP, Intermídia Redes Distribuídas-USP e o Núcleo de Pesquisa em Tecnologia de Arquitetura e Urbanismo-USP. O projeto possui ainda parcerias com a Companhia Habitacional Metropolitana de São Paulo (COHAB-SP) e a Coordenadoria do Governo Eletrônico da Cidade de São Paulo.

O objetivo do projeto é entender as implicações da introdução das chamadas novas mídias na vida cotidiana e suas relações com os espaços de morar. Além da discussão conceitual, o estudo pretende apresentar e examinar dados a partir da intervenção no bairro Cidade Tiradentes, localizado na cidade de São Paulo, através da implantação de comunicação mediada por computadores e outros equipamentos informatizados, através de uma interface colaborativa, especialmente desenhada. Pretende-se avaliar, entre outros, os efeitos de seu uso nas relações sociais, dentro e fora da comunidade, no espaço físico desse fragmento urbano e nas habitações. Este estudo relaciona-se com o campo de ação das políticas públicas, e da inclusão digital, focando o universo das classes sociais menos favorecidas.

É importante ressaltar que esta pesquisa utilizou-se frenquentemente de dados disponibilizados na internet. Para isso buscou-se consultar sites idôneos e oficiais dos projetos analisados. Entretanto foram encontradas muitas dificuldades em trabalhar com sites da internet como fontes de informações, pois muitas vezes a informação desejada não estava disponível, ou o site que a disponibilizava não era confiável, ou havia dados contraditórios entre si, e ainda existia a dificuldade em encontrar os dados corretos frente a grande quantidade de informações existente na internet. A maioria dos sites analizados foram consultados várias vezes durante a pesquisa, para

${ }^{5}$ Para maiores informações visite o site do Comunidades on-line: http://www.eesc.usp.br/nomads/col.htm [acessado em 13/04/2005]. 
atualização e verificação de novos dados, percebeu-se também que alguns sites foram retirados depois de certo tempo, prejudicando pesquisas futuras.

A seguir, tem-se um breve resumo do conteúdo de cada capítulo.

\section{Capítulo 1}

Apresenta um breve relato sobre a história da internet, seu surgimento, desenvolvimento e sua situação atual, com números sobre a quantidade de usuários no Brasil e no mundo. Esses dados sugerem a dimensão da exclusão digital, evidenciando o que significa estar excluído digitalmente na sociedade atual, ou seja, não possuir acesso aos benefícios que as TCls disponibilizam, e a dificuldade que os excluídos encontram para se inserirem no mercado de trabalho. Traça-se um panorama das principais mudanças que as TICs estão provocando na sociedade, nos modos de vida, nos espaços de morar, nos grupos familiares, no trabalho e nas relações sociais. Explica-se o conceito de governo eletrônico, que permite o acesso a serviços on-line, além de possibilitar a melhoria dos serviços públicos direta ou indiretamente. Conclui com a definição do que é software livre, programas abertos livres de restrição proprietária, explicando a sua importância para a inclusão digital, os problemas enfrentados para a sua utilização, e as suas vantagens em relação ao software proprietário.

\section{Capítulo 2}

Define os chamados telecentros, que consistem em geral de um espaço físico, públicos ou não, onde são alocados alguns computadores conectados à internet para uso comunitário. Estes espaços costumam oferecer cursos de informática, e acesso à rede mundial de computadores como suporte para o trabalho, o estudo e o lazer. Notam-se diferenças significativas entre os vários programas de telecentros, além de variações nos serviços oferecidos, na infra-estrutura, e na existência ou não de conexões com outros serviços públicos, como as bibliotecas, postos de saúde, etc.. O modelo de telecentro é utilizado principalmente nos países mais pobres, onde os governos possuem menos recursos para investir, pois este formato é mais barato, mas é também incompleto. 
São analisadas experiências nacionais e internacionais que se baseiam no modelo de telecentro. Porém, pretende-se aqui enfatizar as propostas com vocação para atender às populações mais carentes e que possuam uma proposta de interagir com as comunidades locais de modo a produzir mudanças positivas significativas.

As 14 experiências de telecentros abordadas nesse capítulo são:

Serão analisadas as seguintes experiências nacionais:

1. Governo Federal: Programa Brasileiro de Inclusão Digital.

2. Governo Estadual de São Paulo: Acessa São Paulo.

3. Governo Estadual do Pará: Cidadão Pará.

4. Governo Estadual do Paraná: Paranavegar.

5. Governo do município de São Paulo: Telecentros da cidade de São Paulo

6. Governo do município de Porto Alegre: Telecentros da cidade de Porto Alegre.

7. Governo do município de Curitiba: Digitando o Futuro.

8. Organização não governamental: Comitê para Democratização da Informática.

9. Instituição de caráter privado sem fins lucrativos, Serviço Social do Comércio: Internet livre.

Também serão analisadas as seguintes experiências internacionais:

1. Unesco, atuação em vários países do mundo: Telecentros Comunitários de Multipropósito.

2. Peru: Cabines públicas.

3. Estados Unidos: Community Technology Centers.

4. Inglaterra: Newcastle.

5. Espanha: Telecentros.es. 


\section{Capítulo 3}

Apresentar e analisa algumas experiências de inclusão digital, realizadas no Brasil e no Exterior, que vão além do uso dos telecentros como suporte para a inclusão. Algumas destas experiências possuem telecentros, utilizados como mais uma ferramenta no combate a exclusão digital, além de outros valores agregados, como ênfase na comunicação, desenvolvimento de tecnologias eficientes e de baixo custo, criação de comunidades virtuais, comprometimento na difusão das TICs, entre outros. A maioria destas experiências buscam, para além do combate à exclusão digital, conhecer e explorar o conjunto de novas práticas sociais a partir do uso de equipamentos telemáticos. Procuram, também, incentivar as comunidades locais a pensar sobre o ambiente onde vivem e sobre sua própria inserção nele, de modo a estimular interações que permitam mudanças positivas nestes locais. Procuram, ainda, desenvolver novas tecnologias, mais simples e funcionais, que possuam uma melhor interação homem/máquina, de modo a estimular o desenvolvimento de comunidades virtuais cooperativas, espacialmente referenciadas, capazes de interagir entre si promovendo melhorias nos locais onde vivem, capacitação tecnológica e capacidade de análise critica para obter informações necessárias ao desenvolvimento individual e coletivo destas pessoas.

As oito experiências abordadas neste capítulo são:

Experiências nacionais:

1. Cidade do Conhecimento -USP: Rede Pipa Sabe.

2. Governo municipal de Piraí: Piraí Digital.

3. Governo municipal de Solonópole: Solonópole.

Experiências internacionais:

1. França: SecondTimeZone.

2. Canadá: Netville.

3. Finlândia: Helsinki Virtua/Village.

4. República Dominicana: VAN Bohechio.

5. Índia: CorDECT, Sari e Simputer. 


\section{Princípios da I nclusão Digital}

"A exclusão digital não é ficar sem

computador ou telefone celular.

É continuarmos incapazes de pensar,

de criar e de organizar novas formas,

mais justas e dinâmicas, de produção

e distribuição de riqueza simbólica e material".

Gilson Schwartz, (2000). 


\subsection{A Rede Mundial de Computadores}

Na segunda metade da década de 1980, vários países do mundo, incluindo o Brasil, assistiram à banalização do computador pessoal, que deixou de fazer parte apenas do universo dos escritórios para instalar-se nos lares da classe média. Com a ampliação do acesso à internet, na primeira metade da década de 1990, e sua popularização, primeiramente nos Estados Unidos e depois no mundo, os computadores tornaram-se objetos desejados, inclusive pelas camadas sociais mais pobres ${ }^{6}$, cujos jovens parecem enxergar, no domínio desta máquina complexa, a chance de obter um emprego que lhes permita ascender socialmente. No entanto, devemos lembrar que, atualmente, apenas uma minoria de pessoas tem acesso à internet e, por conseqüência, a uma ampla gama de meios de comunicação. Por enquanto sua difusão maciça se concentra nos Estados Unidos, norte da Europa e em alguns países como o Japão, Canadá, Coréia do Sul, e Austrália. Um dos requisitos essenciais para o acesso à rede mundial é ser alfabetizado e, preferencialmente, ter conhecimentos da língua inglesa.

Invenção que marcou o final do segundo milênio, a internet, como a conhecemos atualmente, é um conjunto de milhares de redes de computadores interligadas entre si. Estas redes surgiram no final dos anos 1960 e início dos anos 1970, e eram, inicialmente, incompatíveis entre si. As tecnologias necessárias para a interligação dessas redes foram desenvolvidas durante a década de 1970 nos Estados Unidos. A criação da rede Arpanet, montada pela Arpa $^{7}$, do Departamento de Defesa norte-americano, é considerado uns dos marcos da origem da internet. Seu objetivo inicial era o de promover a supremacia tecnológica norte-americana sobre os Soviéticos. A criação do protocolo TCP/IP ${ }^{8}$ por Cerf, Postel e Crocker, da Universidade da Califórnia do Sul, permitiu a interligação da Arpanet com as outras redes existentes. Durante a década de 1980, houve um desenvolvimento crescente destas redes interligadas. A World Wide We $b^{9}$ constitui-se, no início da década de 1990, utilizando-se de hipertextos que, segundo Landow (1992), citado por Correia e Andrade (1998), põe em cheque os textos com narrativa linear. De fato, na narrativa hipertextual, o autor oferece múltiplas possibilidades através das quais os próprios leitores constroem sucessões temporais e escolhem personagens, realizando saltos com base em informações referenciais. Juntamente com os hipertextos surgem programas de navegação que compreendem estes textos. Esta história é tratada

${ }^{6}$ Dentro dos limites desta pesquisa serão consideradas pobres ou carentes as famílias com renda mensal inferior a 5 salários-mínimos.

${ }^{7}$ Advanced Research Projects Agency.

${ }^{8}$ Padrão segundo o qual a internet funciona até hoje.

${ }^{9} \mathrm{Em}$ português, rede mundial de computadores. 
por vários autores, mas destaca-se a excelência do relato associativo e abrangente feito por Manuel Castells (2003), em seu livro "A galáxia da Internet".

Atualmente, tudo indica que o número de usuários da internet aumenta a cada dia em todo o mundo tornando-a cada vez mais popular, com exceções muito específicas, como os países em guerra, por exemplo. É, no entanto, essencial ressalvar que as quantificações desse crescimento não são confiáveis. A grande maioria das pesquisas com esse objetivo são realizadas por institutos privados que visam à aplicação comercial destes dados. Isso pode indicar que estes números atendem a interesses de determinados grupos econômicos e políticos, ora minimizando, ora maximizando a realidade. É comum deparar-se com dados contraditórios entre si, produzidos através de metodologias diversas, nem sempre explicitadas, nem sempre confiáveis. Excluem, com freqüência, certas faixas etárias, como, por exemplo as crianças de até 14 anos, e estes números geralmente representam os usuários das classes $A$ e B, onde existe uma grande penetração da internet. A grande dificuldade em se ter acesso à metodologia destas pesquisas, já que muitas são pagas, dificulta ainda mais a interpretação destes dados. Números de institutos oficiais como os do IBGE ${ }^{10}$ e da Unesco ${ }^{11}$ podem ser mais confiáveis. Todavia essas instituições não disponibilizam dados com tanta freqüência e riqueza de detalhes quanto os institutos privados. O número de usuários registrados pelos institutos públicos costuma ser menor, o que pode revelar um maior rigor no trato com os dados e com sua interpretação. Existem ainda levantamentos que incluem os chamados usuários inativos ${ }^{12}$, inchando seus resultados, e outros que ponderam somente os usuários ativos ${ }^{13}$, e nem sempre explicitam este detalhe, o que só vem a aumentar a confusão. Vale lembrar também que a internet é uma entidade altamente mutável, e que dados sobre ela estão sempre se alterando em alta velocidade, apontando, invariavelmente, para um aumento de usuários. As fontes escolhidas para esta pesquisa, como o $A B C$ del Internet, Ibope e outros, consistem basicamente em pesquisas comerciais. Como as pesquisas de órgãos públicos são muito raras e menos específicas em suas verificações, os pesquisadores acadêmicos acabam dependendo dos levantamentos e das análises dos institutos comerciais.

10 Para maiores informações sobre o Instituto Brasileiro de Geografia e Estatística visite o site: www.ibge.gov.br [acessado em:15/05/04].

11 Para maiores informações sobre a Organização das Nações Unidas para a educação, a ciência e a cultura visite o site: www.unesco.org br [acessado em:20/06/04].

12 "Entre 40\% e 60\% de quem pode navegar em casa, efetivamente navega. Como a internet é um fenômeno comercial recente, é comum encontrarmos muitas pessoas que possuem todo 0 aparato tecnológico, incluindo provedor de acesso, para navegarem, mas por não estarem familiarizadas com a rede ou porque não estão cativadas o suficiente para experimentar a internet, não fazem uso dela. É possível que esta distância diminua com o passar do tempo, quando os mais jovens e acostumados à internet sejam maioria nos lares brasileiros." (MAGALHÃES, 2002a).

${ }_{13}$ Assim considerados aqueles que utilizam a rede ao menos para transmitir ou receber e-mails. 
Segundo o site NUA Internet Surveys, o mundo tinha cerca de 605,600 milhões de internautas em setembro de $2002 .{ }^{14}$ Em agosto de 2004, de acordo como o site $A B C$ del Internet, o mundo possuía cerca de 794,790 milhões [ver tabela 1] de pessoas com possibilidade de acesso à rede, o que representa apenas $12,4 \%$ da população mundial.

No final de 1995, o primeiro ano de uso disseminado da world wide web, havia cerca de 16 milhões de usuários de redes de comunicação por computador no mundo. No início de 2001, eles eram mais de 400 milhões; previsões confiáveis apontam que haverá cerca de um bilhão de usuários em 2005, e é possível que estejamos nos aproximando da marca dos dois bilhões por volta de 2010, mesmo levando em conta uma desaceleração da difusão da internet quando ela penetrar no mundo da pobreza e do atraso tecnológico. (CASTELLS, 2003, p. 8).

\section{Tabela 1 - Estatísticas Mundiais da Intemet e de População}

\begin{tabular}{|lrrrrrr|}
\hline \multicolumn{1}{c}{ Tabela 1 - Estatísticas Mundiais da Intemet e de População } \\
\hline Regiões & $\begin{array}{r}\text { População } \\
\text { (2004 Est.) }\end{array}$ & $\begin{array}{c}\text { Usuários } \\
\text { (ano 2000) }\end{array}$ & $\begin{array}{l}\text { Usuários, data } \\
\text { mais recente }\end{array}$ & $\begin{array}{c}\text { Crescimento } \\
\text { (2000-2004) }\end{array}$ & $\begin{array}{c}\text { (\%) População } \\
\text { (penetração) }\end{array}$ & $\begin{array}{c}\text { (\%) de } \\
\text { usuários }\end{array}$ \\
\hline África & 893,197 & 4,514 & 12,253 & $171.4 \%$ & $1.4 \%$ & $1.5 \%$ \\
Ásia & $3,607,499$ & 114,303 & 252,560 & $121.0 \%$ & $7 \%$ & $31.8 \%$ \\
Europa & 730,894 & 103,096 & 222,212 & $115.5 \%$ & $30.4 \%$ & $28 \%$ \\
Oriente Médio & 258,993 & 5,272 & 16,831 & $219.2 \%$ & $6.5 \%$ & $2.1 \%$ \\
América do Norte & 325,246 & 108,096 & 223771 & $107.0 \%$ & $68.8 \%$ & $28.2 \%$ \\
América Latina & 541,775 & 18,068 & 51,181 & $183.3 \%$ & $9.4 \%$ & $6.4 \%$ \\
Oceania & 32,540 & 7,619 & 15,981 & $109.7 \%$ & $49.1 \%$ & $2 \%$ \\
\hline Total Mundial & $6,390,146$ & 360,971 & 794,792 & $120.2 \%$ & $12.4 \%$ & $100 \%$ \\
\hline
\end{tabular}

Fonte: $\mathrm{ABC}$ del internet. Ago/2004. *obs. números em milhões.

${ }^{14}$ NUA Internet Surveys. How Many Online? Disponível em: http://www.nua.ie/surveys/how_many_online/index.html [Acessado em:18/08/04]. 


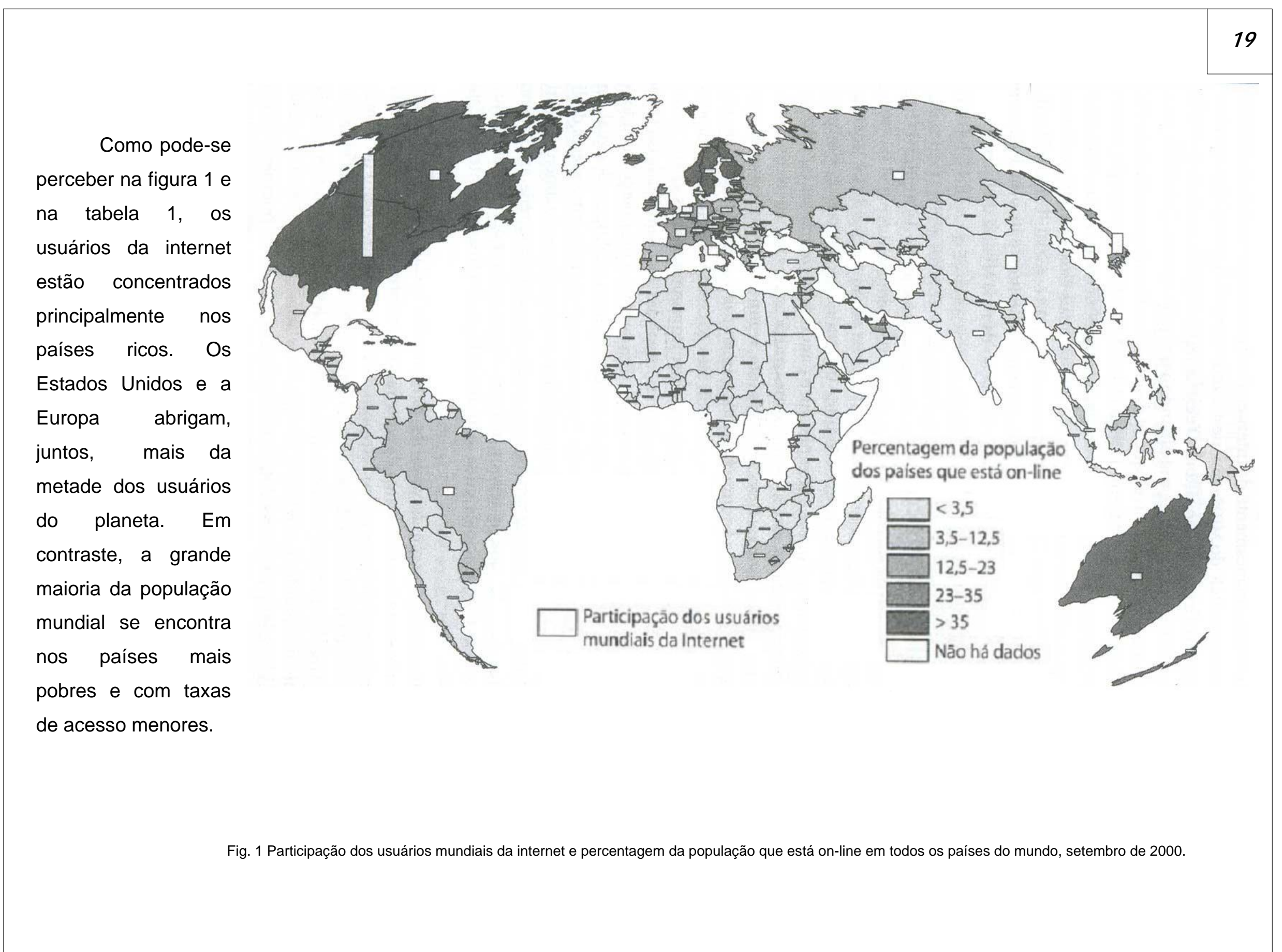


As regiões mais ricas possuem também a maior quantidade de nomes de domínio na internet [figura 2] conhecidos como .com, .org, .net, e código de país [.br no caso do Brasil]. Esse também é um indicador de sua maior participação na rede mundial de

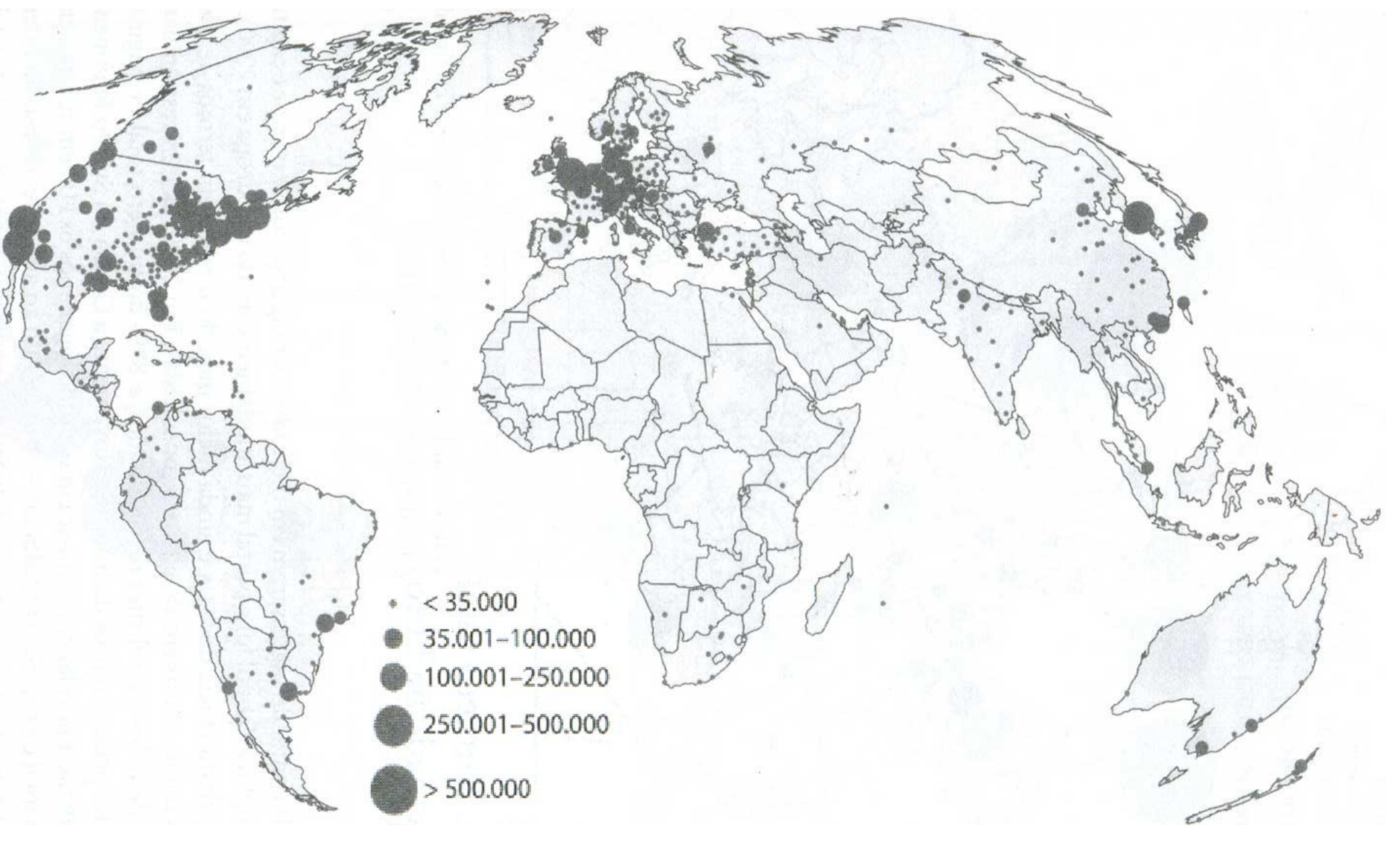

computadores 
No Brasil, uma pesquisa do Datafolha ${ }^{15}$ de agosto de 2001 estimava em cerca de 23 milhões os usuários brasileiros ativos e não $\operatorname{ativos}^{16}$, habitando em regiões metropolitanas e no interior do país. Isso equivaleria a $13,2 \%$ da população do país. Entretanto, a Pesquisa Nacional por Amostra de Domicílios $[P N A D]^{17}$ do IBGE, também de 2001, foi a primeira a verificar a existência de microcomputador nas residências, informando que 12,6\% dos domicílios do país tinham este bem. Segundo a mesma PNAD, 8,6\% dos domicílios tinham microcomputador com acesso à internet, o que confirma que as pesquisas oficiais são menos otimistas que as comerciais. Já em julho de 2004, segundo reportagem do site Portal da Propaganda ${ }^{18}$, o país contaria com cerca de 33 milhões de usuários da rede, com acesso a partir de suas casas, escritórios, universidades, cybercafés e centros públicos de acesso, representando cerca de $19 \%$ da população nacional. Por fim, de acordo com o lbope ${ }^{19}$, os usuários residenciais chegaram a 11,7 milhões de pessoas em maio de 2004.

Contudo, como já foi dito anteriormente, estas pesquisas são feitas visando o mercado, o que as torna, em geral, menos confiáveis. Por exemplo, segundo o site Agência $\mathrm{Clik}^{20}$, em janeiro de 2004, 12 milhões de pessoas acessaram a internet de suas casas, no Brasil, números maiores do que os da pesquisa do lbope de maio de 2004, citada anteriormente. De acordo com a pesquisa de 2001 do Datafolha ${ }^{21}$, apenas $7 \%$ do total dos internautas brasileiros pertencem às classes C e D, as quais correspondem a $42 \%$ da população. Em sua grande maioria, são jovens do sexo masculino, de 14 a 24 anos, que acessam a rede com menor freqüência, em geral, do que classes mais ricas, além de possuírem níveis de escolaridade mais baixos, o que pode implicar na deficiência de compreensão das informações disponíveis na internet, principalmente as que se encontram em línguas estrangeiras. Castells (2003, p. 208) cita pesquisa de 2000 da Cheskin Research, que aponta que $87 \%$ dos websites do mundo estão unicamente em língua inglesa. A figura 3 apresenta

${ }^{15}$ Folha de São Paulo, Revista da Folha - Folha iBrands O Top Of Mind da Internet. São Paulo: Quinta-feira 27 de Setembro de 2001.

${ }^{16}$ A estimativa mais otimista dizia que havia 15 milhões de usuários ativos em janeiro de 2002. (SIQUEIRA, 2002).

17 Para mais informações, ver 0 site. www.ibge.gov.br [acessado em:15/05/04].

18 JULIASZ, F. (2004) A dinâmica peculiar da internet. Disponível em: http://www.portaldapropaganda.com/netmarketing/ami/2004/07/0001 [Acessado em:18/08/04].

${ }_{19}$ IBOPE//NetRatings Brasileiros continuam superando americanos no uso da Internet no domicílio. Disponível em: http://www.ibope.com.br/imprensa/noticias_2004_peoplemeterfor_2004_no.htm [Acessado em:24/06/04].

${ }^{20}$ CABRAL, P. (2004) O Horário nobre da internet brasileira. Disponível em: http://www.agenciaclick.com.br/br/estudos/artigo_1316.asp [Acessado em:18/08/04].

${ }^{21}$ DATAFOLHA, Folha iBrands o top of mind da internet. Disponível em: www1.uol.com.br/folha/datafolha/especiais/ibrands_a.pdf [Acessado em:03/02/02]. 
um gráfico onde se tem as porcentagens das línguas mais utilizadas na internet. O inglês parece ser o mais usado com $35,8 \%$. Já o português representaria apenas 3,5\% do total.

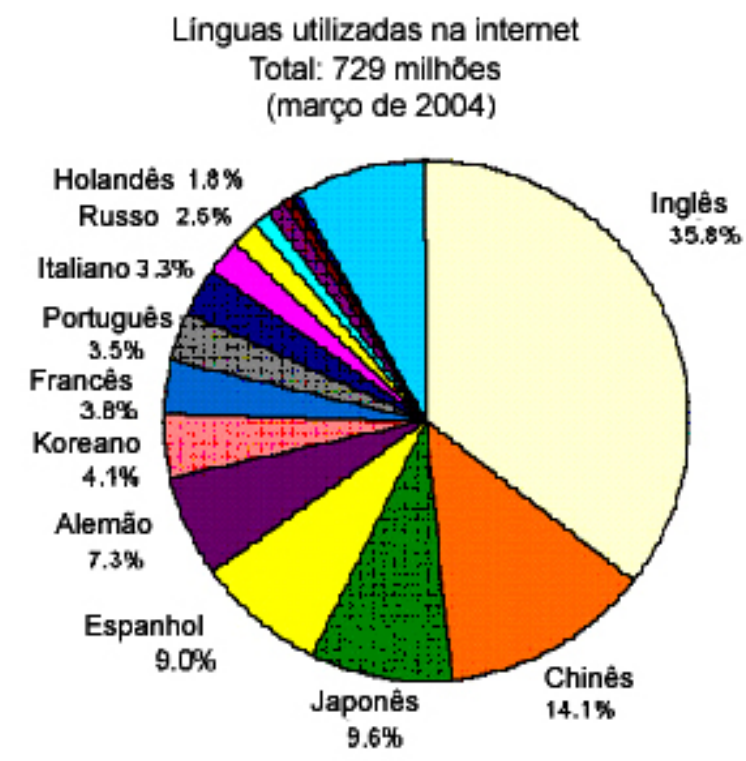

Fig.3 Línguas utilizadas na internet.

Fonte: Global Reach Ago/2004. 
Segundo o analista de internet do Ibope Magalhães (2002) "além do crescimento, que é importante em si, o Brasil se firma como um dos oito maiores mercados mundiais de internet' [ver tabela 2]. Observando-se a tabela 3, verifica-se que o Brasil seria o $10^{\circ}$ país do mundo em quantidade de usuários. Estes números ainda parecem baixos, mas aparentam aumentar a cada dia, à medida que a rede se torna mais popular. O tempo médio de permanência conectado também tende a aumentar. Segundo o lbope ${ }^{22}$, em maio de 2004 , esse tempo foi de $13 \mathrm{hs} 51 \mathrm{~min}$ e colocou o brasileiro em segundo lugar no mundo em termos de horas de uso, atrás somente dos japoneses.

\begin{tabular}{|c|c|c|}
\hline & País & Janeiro/04 \\
\hline $1^{\circ}$ & Estados Unidos & 162.195 .368 \\
\hline $2^{\circ}$ & Japão (.jp) & 12.962 .065 \\
\hline $3^{\circ}$ & Itália (.it) & 5.469 .578 \\
\hline $4^{\circ}$ & Reino Unido (.uk) & 3.715 .752 \\
\hline $5^{\circ}$ & Alemanha (.de) & 3.421 .455 \\
\hline $6^{\circ}$ & Holanda (.nl) & 3.419 .182 \\
\hline $7^{\circ}$ & Canadá (.ca) & 3.210 .081 \\
\hline $8^{0}$ & Brasil (.br) & 3.163 .349 \\
\hline $9^{\circ}$ & Austrália (.au) & 2.847 .763 \\
\hline $10^{\circ}$ & Taiwan (.tw) & 2.777 .085 \\
\hline
\end{tabular}

Fonte: Comitê Gestor da internet no Brasil. Jan/2004.

\begin{tabular}{|c|c|c|c|c|c|c|}
\hline \# & País ou Região & $\begin{array}{l}\text { Usuários, data } \\
\text { mais recente }\end{array}$ & $\begin{array}{l}\text { População } \\
\text { (2004 Est.) }\end{array}$ & $\begin{array}{l}\text { \% População } \\
\text { (Penetração) }\end{array}$ & $\begin{array}{l}\text { Fonte / data } \\
\text { mais recente }\end{array}$ & $\begin{array}{l}\text { (\%) de } \\
\text { Usuários }\end{array}$ \\
\hline 1 & Estados Unidos & $203,271,187$ & $293,271,500$ & \multicolumn{2}{|c|}{$69.3 \%$ Nielsen//NR Jun/04 } & $25.6 \%$ \\
\hline 2 & China & $87,000,000$ & $1,288,307,100$ & $6.8 \%$ & CNNIC Jun/03 & $10.9 \%$ \\
\hline 3 & Japão & $65,933,441$ & $127,853,600$ & \multicolumn{2}{|c|}{$51.6 \%$ Nielsen//NR Jun/04 } & $8.3 \%$ \\
\hline 4 & Alemanha & $45,357,649$ & $82,633,200$ & \multicolumn{2}{|c|}{$54.9 \%$ Nielsen//NR Jun/04 } & $5.7 \%$ \\
\hline 5 & Reino Unido & $35,831,416$ & $59,595,900$ & \multicolumn{2}{|c|}{$60.1 \%$ Nielsen//NR Jun/04 } & $4.5 \%$ \\
\hline 6 & Coréia do Sul & $29,220,000$ & $49,131,700$ & $59.5 \%$ & KRNIC Dic/03 & $3.7 \%$ \\
\hline 7 & Itália & $28,610,000$ & $57,987,100$ & $49.3 \%$ & $\mathrm{C}+1+\mathrm{A}-\mathrm{Dic} / 03$ & $3.6 \%$ \\
\hline 8 & França & $23,216,191$ & $60,011,200$ & \multicolumn{2}{|c|}{$38.7 \%$ Nielsen//NR Jun/04 } & $2.9 \%$ \\
\hline 9 & Canadá & $20,450,000$ & $31,846,900$ & $64.2 \%$ & $\mathrm{C}+1+\mathrm{A}-\mathrm{Dic} / 03$ & $2.6 \%$ \\
\hline & Brasil & $19,760,497$ & $179,383,500$ & \multicolumn{2}{|c|}{$11.0 \%$ Nielsen//NR un/04 } & $2.5 \%$ \\
\hline $10 \mathrm{~F}$ & Países Líderes & $558,650,381$ & $2,230,021,700$ & $25.1 \%$ & IWS - Ago.9/04 & $70.3 \%$ \\
\hline Res & to do Mundo & $236,142,015$ & $4,160,125,169$ & $5.7 \%$ & IWS - Ago.9/04 & $29.7 \%$ \\
\hline Tota & al Mundial de Usuários & $794,792,396$ & $6,390,146,869$ & $12.4 \%$ & IWS - Ago.9/04 & $100.0 \%$ \\
\hline
\end{tabular}

Fonte: $A B C$ del internet. Ago/2004.

${ }^{22}$ IBOPE//NetRatings, Brasileiros continuam superando americanos no uso da Internet no domicílio Disponível em: http://www.ibope.com.br/imprensa/noticias_2004_peoplemeterfor_2004_no.htm [Acessado em:24/07/04]. 


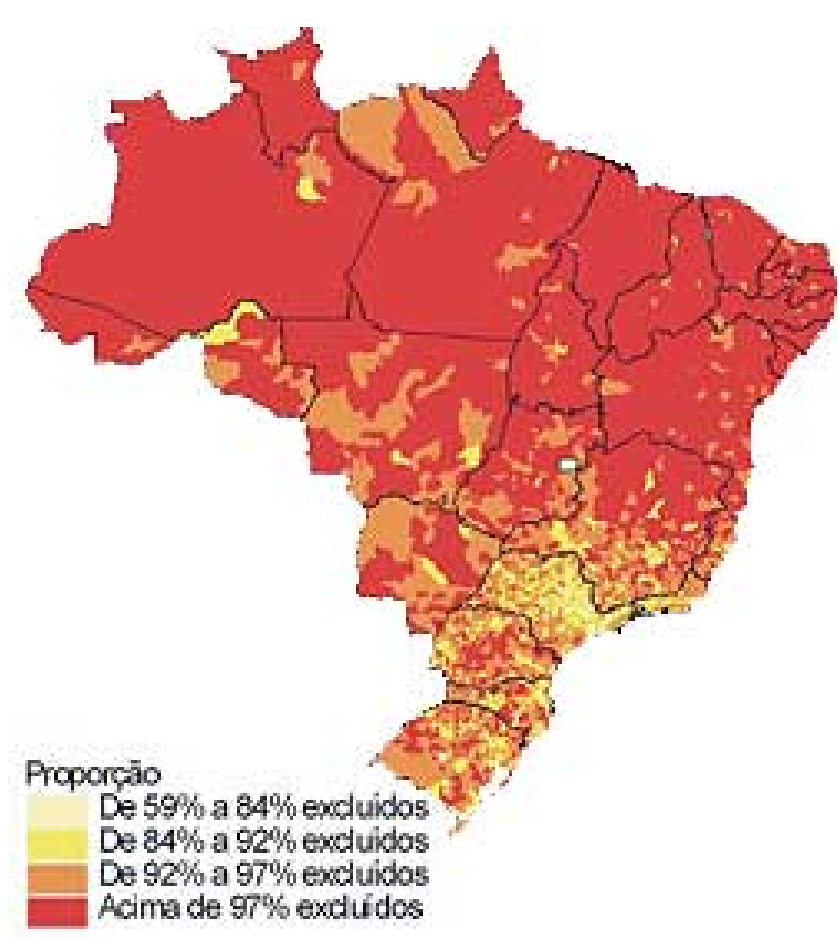

Fig. 4 Mapa da exclusão digital no Brasil

Esse crescimento associa-se à popularização do acesso, e alguns fatores parecem explicar este fenômeno: a redução do preço das assinaturas de provedores de acesso à rede, o surgimento de provedores gratuitos, as iniciativas de disponibilizar acesso grátis em escolas e locais públicos, a alteração de regras do sistema de telefonia brasileiro, que facilitou a aquisição de linhas telefônicas por pessoas com menos recursos, as linhas de financiamento para a compra de computadores $^{23}$, e a redução do preço dos micro-computadores, inclusive usados. Algumas universidades também já desenvolvem computadores a baixo custo para esta parcela da população. Vê-se ainda o surgimento de inúmeras iniciativas públicas, privadas e do terceiro setor para incentivar a disseminação mais ampla destas tecnologias. Entretanto, muito ainda precisa ser feito para combater a exclusão social ${ }^{24}$ que se associa à exclusão digital, impedindo o acesso das camadas mais pobres da população à internet. Na figura 4, tem-se o mapa da chamada exclusão digital no país, onde se percebe que nas regiões mais pobres há uma quantidade maior de pessoas sem acesso à rede.

23 "No primeiro semestre de 2001, o grupo Silvio Santos decidiu financiar computadores com prestações mais acessíveis às pessoas de baixa renda. Surpresos com as vendas de mais de 4 mil unidades diárias, o grupo suspendeu a promoção para se reestruturar, uma vez que suas expectativas foram amplamente superadas e sua capacidade de entrega esbarrava em entraves produtivos e logísticos. 0 que podemos concluir? As pessoas apartadas da sociedade da informação estão percebendo a importância de sua inserção, buscando as menores brechas para não perderem os bits da história. 0 computador pessoal conectado a Internet já é para as famílias uma esperança de um futuro melhor para seus filhos."(SILVEIRA, 2001, p.23.)

${ }^{24}$ RATTNER (2002) define a exclusão social como a privação de grupos, ou indivíduos, de fazerem parte de um grupo social organizado que ofereça meios de gerarem renda própria, moradia, educação, saúde, serviços públicos e privados, lazer, entre outros. 


\subsection{Inclusão Digital}

Com o ascensão da chamada era da informação, viu-se o surgimento de um novo tipo de exclusão social, a exclusão digital. Silveira (2001, p. 18.) comenta que "a exclusão digital ocorre ao se privar as pessoas de três instrumentos básicos: o computador, a linha telefônica, e o provedor de acesso. O resultado disso é o analfabetismo digital, a pobreza e a lentidão comunicativa, o isolamento e o impedimento do exercício da inteligência coletiva". O analfabetismo digital ocorre quando alguém, mesmo sabendo ler e escrever, não sabe utilizar as novas Tecnologias da Informação e da Comunicação, as TICs, em especial a internet. São pessoas que possuem dificuldades em relacionar-se com as interfaces destas tecnologias. É o caso, por exemplo, das pessoas que não sabem fazer ligação de um telefone celular, utilizar um computador ou enviar um e-mail. Já de acordo com Schwartz (2000), "a exclusão digital não é ficar sem computador ou telefone celular. É continuarmos incapazes de pensar, de criar e de organizar novas formas, mais justas e dinâmicas, de produção e distribuição de riqueza simbólica e material".

Discussões e iniciativas têm sido organizadas por setores da sociedade visando permitir que um maior número de pessoas das classes mais pobres tenham acesso a novas formas de pensar e a novos meios de produção de informação: comunicando-se entre si, formando comunidades virtuais, obtendo informações sobre educação [podendo, inclusive, fazer cursos à distância via internet], utilizando serviços públicos [como pagamento de contas], lazer [ouvir músicas, jogar on-line], saúde [marcar consultas], trabalhando [permitindo, inclusive, o teletrabalho], e produzindo conteúdos para a web [como a criação de sites da comunidade]. Contudo, deve-se atentar para o fato de que, nos últimos anos, as expressões inclusão e exclusão digital passaram a ser amplamente utilizadas e, segundo Eisenberg (2002, p. 237), têm sido apropriadas por grupos com as mais diversas agendas, inclusive por governos e empresas que buscam adequá-las aos seus interesses. É, portanto, necessário filtrar as informações que empregam estas palavras visando a perceber os reais interesses por trás de cada iniciativa.

Chagas (2004) afirma que, atualmente, as propostas de inclusão digital “(...)crescem em quantidade, mas não em qualidade. Vários grupos e ONGs passam a criar ações de inclusão digital, que muitas vezes na prática não passam do simples oferecimento à população do acesso às máquinas e cursos de informática básica, que se restringem ao uso dos programas necessários ao trabalho em escritórios e ambientes do gênero". Mesmo em termos quantitativos, estas iniciativas ainda estão muito aquém do necessário para atender à demanda que cresce a cada dia, e o atendimento ainda é precário e geralmente restrito aos grandes centros urbanos. 
Nos dias de hoje, a população de menor renda enfrenta vários problemas para fazer parte da sociedade da informação, principalmente para aqueles que procuram, com recursos próprios, acessar a internet de suas próprias casas. Padecem, por exemplo, da falta de capacitação tecnológica, utilizam equipamentos e software obsoletos, usam os chamados software piratas ${ }^{25}$, têm dificuldade em pagar por uma linha telefônica ${ }^{26}$, em geral não têm acesso a conexões de banda larga, têm dificuldade em arcar com os custos de manutenção dos equipamentos, pouco espaço físico e um grande numero de pessoas morando em suas residências, não dispõem de muito tempo diário para utilizar a internet, e ainda enfrentam a falta de conteúdos destinados a essa faixa da população, pois a grande maioria das páginas da web visam às classes A, B e C.

Ultimamente, o mundo vem passando por uma série de transformações estruturais decorrentes da globalização. A padronização cultural é enorme e interfere nos processos econômicos, políticos e sociais dos países, a uma velocidade muito alta. Freitas (2004) argumenta que as consequências sociais trazidas pela globalização do capital financeiro exacerbaram as exclusões em nossas sociedades. A exclusão digital não ocorre somente com indivíduos ou com comunidades, mas também com grupos, como idosos e deficientes físicos, cidades, empresas, países e até mesmo continentes, como a África, que possui o menor índice de penetração da internet entre a sua população.

No Brasil, dados reconhecidos oficialmente, como os do IBGE, apontam para o crescimento do número de pessoas que vivem abaixo da linha de pobreza. Em virtude das transformações tecnológicas aplicadas nos processos produtivos internacionalizados, fundantes da globalização, a tendência seria a de não haver mais emprego para muitos trabalhadores, resultando no aumento da crise econômica e da subordinação financeira, e no aumento dos índices de violência. Baggio (2002) diz que "o novo trabalhador deve ser um sujeito com permanente capacidade de aprendizagem e de adaptação a mudanças, deve saber trabalhar em grupo, de preferência em equipes multidisciplinares, e ter domínio da linguagem das máquinas. Ou seja: deve também ser alfabetizado do ponto de vista digital". O filósofo Pierre Lévy (1999, p. 175-176) diz, ainda, que "as performances industriais e comerciais das companhias, das regiões, das

${ }^{25}$ Software piratas são cópias de programas comercializados ilegalmente no mercado informal, sem o pagamento dos devidos direitos autorais. São de qualidade inferior [pois são cópias feitas sem controle de qualidade], não possuem garantia, a sua comercialização constitui crime. Por outro lado, possuem o grande atrativo do preço muito inferior ao original, pois não pagam impostos e nem direitos autorais. São fáceis de serem encontrados e difíceis de serem combatidos, pois são distribuídos aos milhares e o seu consumo é intenso principalmente nos países de terceiro mundo onde a fiscalização é ineficaz.

${ }^{26}$ Cuja conexão é lenta [no máximo $56 \mathrm{Kbs}$ ], e os horários mais baratos são de madrugada e nos finais de semana. 
grandes zonas geopolíticas, são intimamente relacionadas a políticas de gestão do saber". Isso significa que o conhecimento e a constante geração de competência são as principais fontes de riquezas de empresas e nações, e, atualmente, os países ricos, através do domínio da tecnologia, subjugam os países pobres e seus modos de produção, como já ocorreu tantas outras vezes durante a história da humanidade.

Na figura 5, uma foto de satélite do mundo à noite permite perceber, pelos pontos claros [as luzes das cidades], a localização dos aglomerados urbanos e os grandes vazios populacionais. Uma leitura aproximativa, ainda que não corresponda fielmente à realidade, revela, ainda, que as áreas mais iluminadas são as que possuem as maiores concentrações de renda, e, portanto, maiores oportunidades de inclusão social e digital.

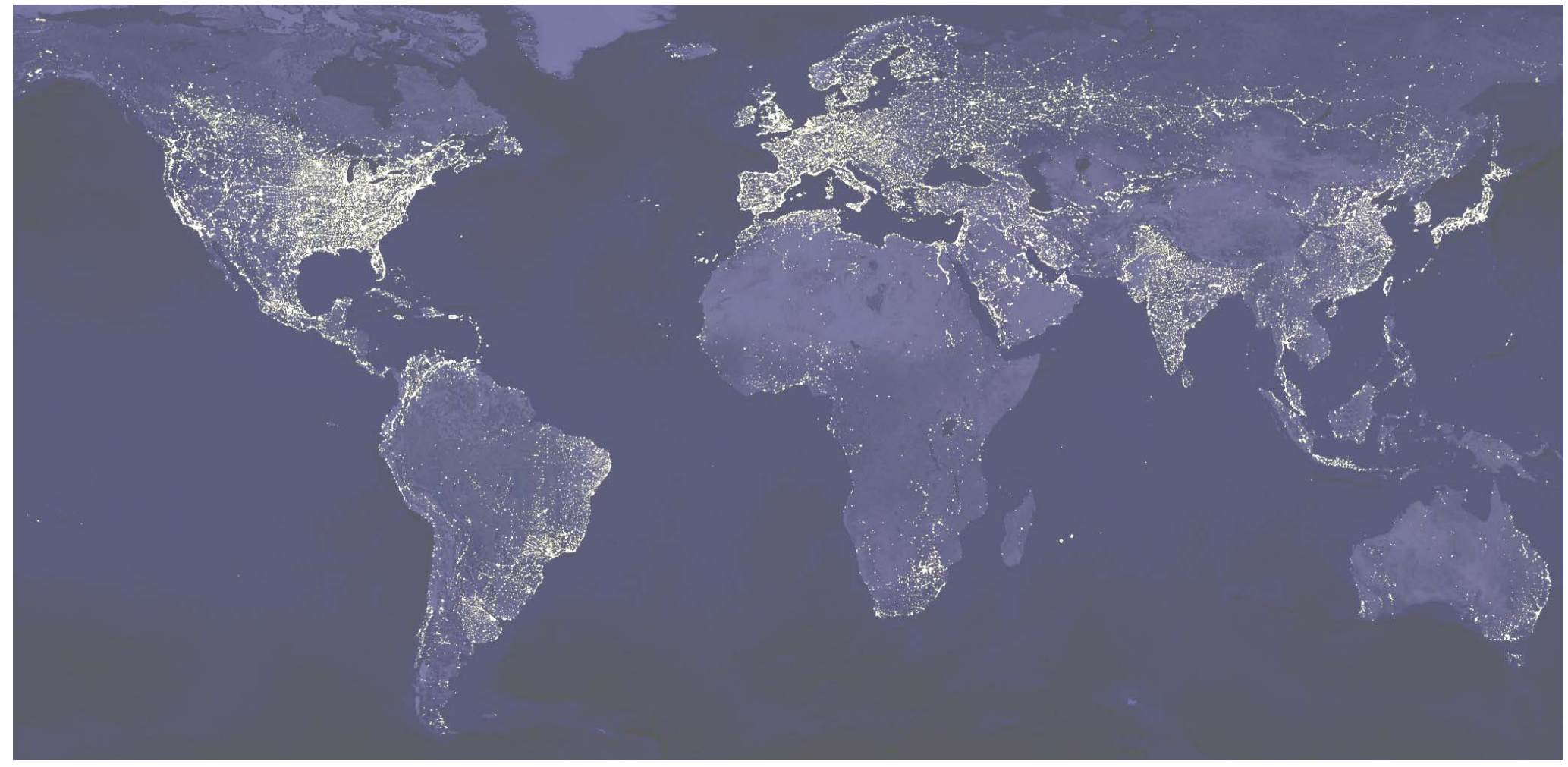




\subsection{A Formação de uma Nova Sociedade}

Com a popularização das TICs, novas possibilidades inclusivas podem ser potencializadas. Dentre elas está a organização de comunidades e movimentos sociais através da internet, pois, de acordo com Castells (2003, p. 119), a rede "fornece a base material que permite a esses movimentos engajarem-se na produção de uma nova sociedade". Também Silveira (2003a, p. 22) lembra que "(...) todo período histórico possui um conjunto de tecnologias que as sociedades dominantes - e dentro delas, suas elites - utilizam como fonte especial de poder e de reprodução da riqueza". Takahashi (2000, p. 59) complementa dizendo que "a informação, as telecomunicações, as novas mídias, a informática em geral e a indústria eletro-eletrônica passaram a ocupar lugar central no processo de acumulação de capital. Como efeito imediato desse processo, promove-se globalmente a privatização e a desregulamentação do setor. Nesse novo quadro, a tecnologia aprofunda e estende a habilidade das empresas para transformar em mercadorias os produtos da telemática - que são informações em todas as suas formas".

Alguns estudiosos são mais otimistas, acreditando que a disseminação das TICs entre a população carente pode ser apenas uma questão de tempo. Beting (2002), por exemplo, afirma que "a penetração das novas tecnologias se faz em ritmo de uma Ferrari em sexta marcha. A telefonia precisou de sete décadas para cobrir metade da Humanidade. O rádio contentou-se com meio século, a televisão não passou de 28 anos e a internet ensaia ficar abaixo de 10 anos - desde 1996". O avanço das tecnologias de transmissão e produção de informação, e o seu consequente barateamento e banalização, está conduzindo a humanidade, segundo Negroponte (1995, p. 157), à era da "pós-informação"27. De acordo com o autor, a era industrial baseava-se em átomos - ou seja, o produto tinha uma forma física palpável -, linhas de produção seriadas, e foi marcada por grandes avanços científico-tecnológicos, como o surgimento de novos meios de comunicação (rádio e telefone), novos meios de transporte (automóvel e avião) novas fontes de energia (elétrica e o petróleo) e novos materiais de construção, como o concreto armado. Já a chamada era da Informação inicia-se no segundo pós-guerra. Como afirma Tramontano (1998, p.189),

A vitória aliada na Segunda Guerra Mundial consolida a cultura norte-americana como novo referencial de costumes para toda sociedade mecanizada que se queira moderna. (...) De forma subjacente, a difusão do american way of life é garantida, dentro e fora dos Estados Unidos, pelo mais poderoso e mais abrangente meio de comunicação de que

27 "Discute-se tanto e há tanto tempo a transição da era industrial para uma era pós-industrial ou da informação que é possível que não tenhamos notado que estamos passando para uma era da pósinformação". (NEGROPONTE, 1995, p. 157). 
se havia tido notícia até então: Hollywood. O cinema, que atraía multidões, era a máquina perfeita para a missão de divulgar produtos como eletrodomésticos, cigarros e automóveis, mas também maneiras de viver às quais tais produtos eram imprescindíveis.

A era da informação já se prenunciava a partir de meados do século $X X$, focalizada nos Estados Unidos como nação mentora desse processo, já que lá se iniciaram as principais transformações tecnológicas, como a disseminação do uso dos computadores e dos meios de comunicação em massa, a banalização da televisão a cabo, e, mais recentemente, o surgimento da internet, da telefonia celular e dos computadores portáteis, que minimizam a importância do espaço, passando a equipar o indivíduo, em qualquer lugar.

Atualmente, comentam-se as profundas alterações no modo de morar, advindas da informatização da vida cotidiana. $O$ computador pode, por exemplo, induzir mudanças nas funções dos cômodos da habitação. O quarto de dormir, que era, historicamente, um ambiente de descanso e isolamento passa a ser também, muitas vezes, um ambiente de trabalho e convívio, acumulando funções não previstas no programa convencional de habitação. Mudanças no espaço doméstico também começam a ocorrer em função de novos perfis demográficos, já que o conceito de família nos dias de hoje não engloba somente a antiga configuração pai, mãe e filhos, mas também de novos grupos domésticos.

À nuclearização da unidade familiar, cujo processo estende-se desde, pelo menos, o século XVI até os nossos dias, seguiu-se seu estilhaçamento, potencializado, na segunda metade do século $X X$, quando surgem novos formatos de grupos domésticos: famílias monoparentais, casais DINKs - Double Income No Kids -, uniões livres - incluindo casais homossexuais -, grupos coabitando sem laços conjugais ou de parentesco entre seus membros, e uma família nuclear renovada, ainda dominante nas estatísticas, mas com um enfraquecimento da autoridade dos pais em benefício de uma maior autonomia de cada um de seus membros. Todos passos em direção a um - aparentemente - novo padrão social: pessoas vivendo sós. As causas desta evolução são inúmeras e, relativamente, recentes. (Tramontano 1998. p. 196).

O surgimento das novas mídias e da informatização da vida cotidiana potencializa mudanças nas relações do grupo familiar e deste com outros. Um exemplo plausível é a possibilidade de uma pessoa poder conversar com um desconhecido em outro continente, via internet, eventualmente com maior intimidade do que com um familiar que vive no quarto ao lado do seu. Tramontano diz ainda que

(...) o uso efetivo dos cômodos da casa convencional permanece em constante alteração, mesmo que raramente o programa de necessidades reconheça este fato e, mais raramente ainda, o projeto arquitetônico o legitime. Esse processo tende a tornar-se cada vez 
mais complexo, com o desenvolvimento, em curso, de novos equipamentos que concentrem, por exemplo, as funções de televisão, telefone e computador ligado à internet. A sobreposição de funções não está prevista no modelo convencional de habitação, que, por incrível que pareça, ainda guarda feições burguesas parisienses oitocentistas, mesmo quando abriga parcelas pobres da população. (2003b, p.118 e 119).

Estas mudanças nos modos de vida indicam a necessidade de revisão, por parte dos arquitetos, do conceito e do desenho atual da habitação.

Alguns pesquisadores como Dertouzos (2000, p. 46), se perguntam quais os impactos negativos que a chamada era da informação pode trazer, como a troca dos relacionamentos físicos humanos pela proteção artificial da realidade virtual, a perda de postos de trabalho, o aumento das desigualdades sociais, a perda da privacidade devido ao controle do conteúdo acessado por parte do Estado, variados níveis de exclusão digital - até mesmo entre pessoas com renda mais elevada, mas que possuem dificuldades em compreender as novas mídias -, estariam entre estes fatores negativos. Já Castells (2003, p. 102) aponta pesquisas que assinalam que a internet possui um efeito positivo sobre a interação social, e contribui para melhorar a vida social dos seus usuários com a família e os amigos. 0 que pode-se supor é que todas estas transformações são muito recentes historicamente, e ainda não há um consenso das reais influências positivas e negativas das TICs.

Dentre as possíveis aplicações das TICs, poderíamos mencionar o teletrabalho, que tende a minimizar os deslocamentos físicos no espaço urbano, possibilitando que o trabalhador execute tarefas fora do ambiente do escritório, ilustrando certas faces do conceito de telepresença, como formulado pelos historiadores da Humboldt-Berlin Universität, Grau e Reichle (1999, p. 31). Hoje em dia, é tecnicamente possível executar tarefas [escrever um e-mail, ligar para alguém, entre outras] praticamente em qualquer ambiente urbano com o auxílio dos celulares, palms, notebooks, e outros dispositivos móveis Isto permite uma economia do esforço, do custo e do tempo gasto para se percorrer o espaço concreto, podendo acarretar vantagens como maior contato com a família, incluindo as crianças, a redução de tráfego e a diminuição da poluição. Uma série de desvantagens pode igualmente ser mencionada, como a sobreposição às vezes indesejada das esferas privada e pública, o aumento das horas trabalhadas, maior peso da jornada dupla feminina, além de indefinições sobre os limites entre os conceitos de privado e público. Apesar de controvertido, o conceito de teletrabalho tem sido difundido entre profissionais liberais, empresários e todos aqueles que podem levar o trabalho para fora do escritório. No entanto, os 
estudos de November (1997) sobre o teletrabalho o dividem em duas faixas de atuação: uma, de pessoas intelectuais e altamente capacitadas, e a outra, de pessoas pouco qualificadas, que executariam tarefas repetitivas, como por exemplo vigiar monitores de câmeras de segurança.

Os sistemas informatizados também podem ser utilizados para a monitoração de crianças ou de pessoas doentes, através do conceito de homecare. Frente a algum problema de saúde, o usuário poderia interagir com o médico a partir de um sistema informatizado, iniciando um check-up via internet. Também permitem a portadores de mobilidade reduzida, deficientes visuais e a população idosa, que está aumentando significativamente no Brasil e no mundo, uma maior autonomia. Com estas tecnologias, comandáveis através de sistemas de reconhecimento de voz, controles remotos, sensores presenciais, e sem a automatização de certas funções domésticas, essa população teria a possibilidade de não depender unicamente de terceiros. Um bom exemplo é a Rede Saci, uma organização que fornece soluções para facilitar a comunicação e a difusão de informações sobre deficiências. No site da Rede $\mathrm{Saci}^{28}$ é possível encontrar uma série de programas para os portadores de deficiências se integrarem à sociedade da informação. Estes conceitos poderiam ser úteis para a população de baixa renda, que não pode pagar por esses serviços, como os mais ricos.

Vale também lembrar que os idosos são uma das parcelas da população que possui maiores dificuldades para se adaptar ao uso de computadores. Neste sentido, interfaces ${ }^{29}$ mais amigáveis e inteligentes possibilitam também sua inclusão, diminuindo o tempo necessário para se aprender a utilizar um computador corretamente. Alguns avanços já são percebidos, como o uso de microfones, que podem, inclusive, substituir o telefone em conversas via internet, pequenas câmeras acopladas ao computador, conhecidas como webcams e, ainda rara, a utilização de comandos de voz. Deve-se destacar, ainda, a importância do comércio eletrônico que movimenta a economia, gera novas opções de consumo, também minimiza deslocamentos físicos, e ajuda a acelerar a penetração das TICs na sociedade, gerando uma demanda por novos investimentos no setor.

Paralelamente, têm sido desenvolvidas outras interfaces, como o uso de programas inteligentes denominados agentes ${ }^{30}$, telefones celulares, e a combinação televisor e set-top box ${ }^{31}$. Pode-se dizer que tanto o telefone celular, principalmente os modelos pré-

${ }^{28}$ Mais informações no site da Rede Saci: www.saci.org.br [Acessado em:18/10/04].

29 "Uma interface homem/máquina designa o conjunto de programas e aparelhos materiais que permitem a comunicação entre um sistema informático e seus usuários humanos". (LÉVY 2001. p. 176).

30 São programas que vão se adaptando às necessidades do usuário, com o uso contínuo permitindo um uso mais eficiente da interface.

${ }_{31}$ É um decodificador de sinais digitais ou analógicos, que permite navegar na web pelo televisor, jogar on-line, gravar dados em HDs virtuais, receber e-mails, etc. 
pagos, quanto o televisor são equipamentos já amplamente presentes na habitação da população de baixa renda. O desenvolvimento de novos sistemas para infra-estrutura de redes também permite o barateamento das TICs. Pode-se citar, como exemplo, o uso da internet via rede elétrica (PLC), que está em fase de teste em algumas cidades brasileiras, inclusive em São Paulo. Aranha foi o responsável pelos testes na cidade de Belo Horizonte e afirma ${ }^{32}$ que este tipo de conexão possibilita atender a um número muito maior de usuários, por um custo menor. Contudo, ainda são necessários aperfeiçoamentos para que o sistema seja estável, além da regulamentação da legislação, para que possa ser explorado comercialmente.

Entre os usos possíveis da rede mundial de computadores, considera-se a possibilidade de formação das chamadas comunidades virtuais $^{33}$, cujo conceito é amplo e controvertido, uma vez que a definição clássica do termo comunidade pressupõe a referência territorial. Associada à qualificação "virtual", a expressão designa comumente desde grupos com interesses comuns, em vários níveis, existentes na internet, às redes intranet. $\mathrm{O}$ que interessa especificamente na presente pesquisa, quando se trata de comunidades virtuais, são precisamente os grupos de pessoas que se intercomunicam através das TICs e que, ao mesmo tempo, pertencem a uma mesma localidade delimitada fisicamente, como conjunto residencial, bairro, vizinhança, comunidade rural, entre outros. Estas comunidades podem fortalecer o sentimento de identidade comum e permitir a união para a solução de problemas da coletividade. Silva (2002) comenta ainda que, atualmente, assiste-se

(...) a uma aceleração do metabolismo social. Geram-se as chamadas comunidades virtuais que se sustentam na partilha intelectual e na convergência da pluralidade e riqueza dos conhecimentos que emanam dos sujeitos. Nestes novos espaços sociais geram-se novas solidariedades, novos excluídos, novos mecanismos de participação, novas formas de democracia, de negociação, de decisão, de cooperação, de afectividade, de intimidade, de sociabilidade que potenciam a emergência de sujeitos colectivos ou de inteligências colectivas conectivas.

${ }^{32}$ Entrevista realizada em 11 de novenbro de 2003 pela pesquisadora do Nomads.usp Arq. Ângela Campos de Pinho com Ângelo de Barreto Aranha, engenheiro elétrico da CEMIG [Companhia de Energia de Minas Gerais] do Departamento de Tecnologia da Informação.

33 "As chamadas comunidades virtuais, embora apresentem múltiplas características, constituem uma realidade difícil de ser contestada. Mas está longe ainda o consenso entre os pesquisadores com relação às novas questões no âmbito da sociabilidade. Entre as análises de cientistas sociais que, de forma pessimista, enxergam no futuro o fim das relações sociais face-a-face, e àquelas precavidas ao extremo, que ignoram alterações significativas nos vínculos sociais, somam-se ainda as que exploram as evidências disponíveis deste processo de construção de novas bases das relações em sociedade, centrando parte de suas análises nas comunidades virtuais. Em muitos destes estudos, parte-se do princípio de que comunidade é não apenas uma sociabilidade local, baseada em limites geográficos, centrada em relaçôes face-a-face, mas uma instância onde valores e interesses são partilhados, onde está presente a sensação de pertencimento."(Tramontano et al. 2004a, p. 2) 
Já segundo Assumpção (2001, p. 27), "a formação de comunidades virtuais parece ser uma preocupação predominantemente européia e latino-americana." $\mathrm{Na}$ Europa, os projetos de cidades digitais ${ }^{34}$ são política oficial da União Européia. Como exemplo interessante, pode-se citar a rede Iperbole ${ }^{35}$ da cidade de Bolonha na Itália. As cidades digitais são um tipo de comunidade virtual, e muitas vezes funcionam como um portal de serviços públicos e/ou privados de uma determinada região, cidade ou comunidade. Podem, inclusive, ser um bom meio de o Estado prover serviços para a população através do chamado governo eletrônico.

As comunidades virtuais podem produzir melhorias significativas na vida das pessoas marginalizadas. Podem, inclusive, promover novas oportunidades de emprego a partir da capacidade de organização da própria sociedade. Os telecentros podem ajudar a viabilizar estas comunidades, pois tratam-se de espaços concretos onde as pessoas se encontram para acesso ao espaço virtual, possibilitando, ainda, a formação de agentes multiplicadores dos conhecimentos digitais, e também de novas práticas envolvendo este universo. Em contraponto, Castells (2003, p. 98 e 99) acredita que, em sua grande maioria, estas comunidades seriam, na verdade, indivíduos em rede que utilizam a internet para fins puramente práticos, ligados ao trabalho, à família, aos amigos e a vida cotidiana, através da comunicação por correio eletrônico, que representaria, segundo o autor, mais de 85\% do uso atual da internet. Castells afirma que estas pessoas tenderiam a reproduzir, no ambiente virtual, as mesmas práticas sociais que conheciam antes de utilizarem a internet.

34 "Cidade Digital, Cibercidade, Digital City, Telecities, são denominações usadas para um fenômeno que ainda está sendo mapeado, sem uma definição precisa. De maneira geral é possível entendê-la como um sistema de pessoas e instituiçóes conectadas por uma infraestrutura de comunicação digital (internet) que tem como referência uma cidade real, física". (Moraes, 2002).

35 Para mais informações, visite o site: www.iperbole.bologna.it [acessado em:19/06/03]. 


\subsection{Governo Eletrônico}

Da perspectiva néo-liberal vigente no Brasil desde os primeiros tempos da internet, em 1994, o papel do Estado, neste contexto, é o de regular as várias condições necessárias para promover a expansão da base tecnológica, através de várias ações como a isenção de impostos, de modo a permitir a ampliação da chamada sociedade da informação com o menor número possível de excluídos. O Estado pode também agir definindo políticas públicas para investimentos em pesquisas que possibilitem a criação de hardware e software nacionais, minimizando importações e gerando empregos, criando uma cultura do uso e produção de novas mídias para o país, além de promover iniciativas de combate à exclusão social, investindo em locais onde não há interesse de segmentos econômicos da sociedade. Uma das formas de se fomentar esse desenvolvimento é a utilização de serviços governamentais on-line,o chamado governo eletrônico, ampliando, assim, os canais de comunicação entre o governo e a sociedade.

Castells (2003, p. 114) assinala ainda que "uma vez que a internet está se tornando um meio essencial de comunicação e organização em todas as esferas de atividade, é obvio que também os movimentos sociais e o processo político a usam, e o farão cada vez mais, como um instrumento privilegiado para atuar, informar, recrutar, organizar, dominar e contradominar". Sendo assim, diversos governos democráticos, através de suas esferas federal, estadual e municipal, têm procurado, através da internet, fortalecer a sua legitimidade pela criação de novos canais de participação do cidadão. Estes canais permitem o acesso a serviços públicos informatizados, entre eles solicitações de determinados documentos, disponibilização de informações gerais e específicas sobre a administração pública, além da possibilidade de interlocução direta, menos burocratizada, entre o poder público e o cidadão. Isto permite economia de recursos e de tempo tanto por parte dos órgãos públicos como do cidadão. Algumas vezes, é possível até mesmo fiscalizar os gastos públicos que são disponibilizados na internet. Contudo, a quantidade, qualidade e o tipo de serviços oferecidos variam muito entre as diferentes esferas públicas e as diferentes administrações, o que dificulta o uso destas informações. Muitos destes serviços continuam disponibilizados nas instâncias administrativas presenciais, concretas, pois o número de excluídos digitais ainda é grande.

A ampliação destes serviços requer um alto investimento em infra-estrutura: seja em cabos, para interligação das redes, em computadores, software - o uso de software livre pode significar uma grande economia de recursos -, capacitação de pessoal, manutenção, entre outros. Imagina-se que a implantação de sistemas de informatização podem ter seu custo reduzido se houver parcerias entre a sociedade organizada (ONGs), Estado, entidades de ajuda internacionais, iniciativa privada, universidades e fundações. 
As universidades podem certamente disponibilizar tecnologia e pesquisadores, inclusive desenvolvendo novas tecnologias de rede, de hardware - como é o caso da TV digital ${ }^{36}$ - e programas em software livre específicos para administrações públicas. Atualmente, muitas destas parcerias já existem, e há um interesse mútuo entre universidades, empresas e instâncias do poder público, que pode ser melhor explorado.

A interligação dos órgãos públicos por meio de suas ações e práticas conjuntas usando a internet também é muito importante, pois pode permitir a economia de recursos, agilidade para práticas administrativas, e o cruzamento mais eficaz de informações de diferentes bancos de dados. Um exemplo é a aproximação dos bancos de dados das polícias militar e civil, que pode assim melhorar o combate ao crime.

Os chamados crimes da internet, como o ataques de hackers a bancos de dados privados e públicos, a invasão de sites públicos, a criação de vírus, entre outros, também são uma preocupação de governos de todo o mundo. Assim como a grande quantidade de sites exibindo conteúdos de pedofilia, de racismo e de terrorismo difíceis de serem combatidos, necessitam de um maior controle por parte do Estado. Parte destes crimes pode ser combatida através da criação da certificação digital, que são assinaturas digitais criptografadas. $O$ Instituto Nacional de Tecnologia da Informação ${ }^{37}$ é o órgão do governo federal brasileiro responsável pela criação de um padrão nacional de certificação digital, além de adotar como postura política a disseminação do uso do software livre no território nacional.

Entrevêem-se também avanços em áreas como saúde e educação, por exemplo, se apenas fosse possível o acesso à internet a partir de áreas isoladas do território nacional, através de programas governamentais e parcerias com empresas privadas. Associadas à informatização, já em curso, de toda a cadeia de profissionais, instituições e serviços nestas áreas, tais iniciativas seriam talvez capazes de transformar a vida daquelas populações.

${ }^{36} \mathrm{O}$ desenvolvimento de um padrão brasileiro ainda está sendo pesquisado pelo Laboratório de Sistemas Integráveis da USP. http://www.lsi.usp.br [acessado em:14/03/05].

${ }^{37}$ Para mais informações visite 0 site: http://www.iti.br/ [acessado em:19/05/04]. 


\subsection{Software Livre}

Silveira (2001, p. 38 e 2003a, p. 36) afirma que software livre são programas abertos, livres de restrição proprietária quanto à sua cessão, alteração e distribuição. Sendo assim, um programa aberto deve assegurar a todos acesso irrestrito ao seu código-fonte, possibilitando a alteração de suas características originais, o seu aperfeiçoamento e sua adequação às necessidades dos usuários. Essas modificações não são possíveis em software proprietário ${ }^{38}$. Cabe ressaltar, porém, que o software livre não é ,necessariamente, gratuito. O patrono e maior teórico do movimento do software livre é o norte americano Richard M. Stallman, presidente da Free Software Foundation $^{39}$, criada em 1985 para reunir e distribuir programas de código-fonte aberto e também para produzir um sistema operacional livre com a lógica do sistema Unix ${ }^{40}$. Com a difusão da internet, o movimento se espalhou pelo mundo. Em 1992, o finlandês Linus Torvald conseguiu reunir todos os programas do movimento software livre em torno de um núcleo central, que viabilizou a criação de um sistema operacional, que ele denominou Linux. A Free Software Foundation também criou o conceito de copyleft ${ }^{41}$ para evitar que os esforços do movimento fossem apropriados indevidamente e patenteados por alguma empresa. Hoje em dia, o Linux é utilizado em uma grande quantidade de países além de possuir mais de 400 mil desenvolvedores voluntários pelo mundo todo.

É correto afirmar que ações de inclusão digital sem o uso de software livre têm sentido incompleto, pois os recursos utilizados para o pagamento das licenças poderiam ser utilizados em outras despesas mais relevantes. Segundo o Livro Verde do governo federal (TAKAHASHI 2000, p. 72)

O custo de software, em comparação com os custos decrescentes de hardware, tem se tornado cada vez mais significativo. No caso de governos, o problema não se refere somente ao desenvolvimento de novos aplicativos, mas (e talvez principalmente) ao licenciamento de cópias de produtos de software para uso em milhares de equipamentos. A recente emergência do Sistema Operacional Linux e de aplicativos associados tem trazido, à pauta de discussões em vários países, a hipótese de adoção de uma estratégia baseada em software abertos para aplicações governamentais. Há, em contraposição, uma tendência ao oferecimento de novas formas de comercialização de

38 "Programas de computador com código fonte fechado [0 que significa que não é possível modificar estes software para atender as necessidades específicas de cada usuário], patenteado por uma única empresa, que cobra direito de propriedade intelectual. Se alguém abrir, alterar ou divulgar esse código-fonte, é considerado um criminoso. Quem duplica, distribui ou usa esse tipo de programa sem pagar royalties, violanto copyrights, comete o crime de pirataria". (CASSINO, 2003).

${ }^{39}$ Para maiores informações sobre a Free Software Foundation visite o site www.fsf.org [Acessado em 15-08-04]

${ }^{40}$ Sistema operacional desenvolvido nos anos 60 e 70 por pesquisadores do Massachusetts Institute of Technology [MIT ]e por empresas particulares sendo utilizado até hoje.

${ }^{41}$ Copyleft em inglês é um jogo de palavras; como é bem sabido copyright é o direito de impedir a cópia de um bem artístico ou intelectual, sendo formado pela união de duas palavras copy (cópia) e right (direito). Copyleft por sua vez está formado por duas palavras: copy (cópia) e left que pode ser traduzido tanto por esquerdo como pelo particípio do verbo leave (deixar, abandonar). Poderíamos traduzir copyleft por deixar copiar. Trata-se de um registro que impede a restrição de seu uso e a cobrança de direitos, tornando-o oficialmente propriedade pública. 
software por parte dos fabricantes, utilizando mecanismos de distribuição de redes, contemplando aluguel (e não licenciamento definitivo) de software por tempo limitado, reempacotando funções em opções mais variadas para os usuários etc. Essas medidas tendem a baratear os preços de software,a médio prazo.

Sendo assim pode ser que o mercado reaja ao software livre barateando o preço para o consumidor final, de modo a facilitar a aquisição de software proprietário. Cruz (2004, p. 33) complementa que

A questão do uso de software livre ou proprietário está mais relacionada à definição de uma política de informática do que de uma política de inclusão digital. O usuário comum de computador, que utiliza programas como o navegador de Internet e o processador de textos, consegue passar de forma relativamente tranqüila de um tipo de software a outro. O ideal seria que fosse preparado para usar os dois ambientes de software. O Windows, da Microsoft, tem mais de 90\% do mercado de sistemas operacionais para microcomputadores. Este fato é usado, ao mesmo tempo, pelos defensores do software livre e pelos defensores do software proprietário. Para quem prefere o Linux, o uso do Windows nos programas de inclusão digital reforçaria a posição "monopolista" da empresa americana. Para quem prefere o Windows, o uso do Linux e de outras soluções de software livre não prepararia as pessoas para o mercado, já que as empresas usam principalmente as soluções da Microsoft.

De seu lado, já existem empresas liberando o uso do código fonte de seus programas. Como afirma a revista eletrônica Valor Online ${ }^{42}$ "a Microsoft decidiu abrir o código-fonte do Windows e de outros produtos para clientes empresariais, universidades e governos. o cliente não pode modificar o coração do sistema como ocorre com o Linux, mas ao entender como ele funciona pode criar ou modificar outros programas, para que eles 'rodem' melhor sobre o Windows". Esta é uma guerra que mal começou e ainda está longe de terminar, e que aparentemente pode também trazer benefícios aos usuários finais.

Os entusiastas do movimento software livre enxergam o Linux como uma das grandes soluções para o problema da exclusão digital. Mas então por que aparentemente o Linux não é utilizado amplamente nesses programas de inclusão, e por que há tanta resistência ao seu uso?

42 VALOR ONLINE, Microsoft reforça guerra ao Linux. Disponível em: http://ultimosegundo.ig.com.br/materias/mundovirtual_especial/1906501-1907000/1906518/1906518_1.xml [Acessado em 12-03- 
Primeiro, há a questão de que o software proprietário é o padrão do mercado mundial, constituindo um poderoso monopólio. Se alguém procura um emprego que exija conhecimentos de informática, é bem provável que os programas sobre os quais conhecimentos a empresa exija conhecimento, sejam de software proprietário.

Segundo, a variedade de programas de software livre ainda é pequena se comparada aos de software proprietário, principalmente em relação a programas de entretenimento, como os jogos. Se alguém precisar de um programa não usual terá dificuldades para encontrá-lo, e, dependendo do programa, talvez nem exista uma versão adequada ao Linux.

Terceiro, os programas feitos para Linux são incompatíveis com os sistemas operacionais de software proprietário, que muitas vezes também são incompatíveis entre si, e vice-versa ${ }^{43}$. Este é um dos principais fatores de resistência das pessoas em relação ao uso do Linux, pois quem está acostumado a utilizar um determinado programa proprietário e quiser usar o Linux terá que reaprender a utilizar um programa semelhante deste sistema. Entretanto, geralmente, a linguagem gráfica dos dois programas de sistemas diferentes costuma ser parecida, justamente para facilitar a readaptação.

Quarto, como ainda não existe uma cultura do uso do software livre disseminada na população - muitos nem sabem que existe software livre -, fica difícil conseguir assistência técnica, ainda cara e pouco disponível, novos programas e atualizações.

Por último, há o evidente problema dos interesses das grandes empresas multinacionais de software, que obviamente não desejam perder mercado para o software livre, e fazem de tudo para impedir o seu avanço.

Como afirma Aquistapasse ${ }^{44}$, a principal dificuldade do uso do software livre é cultural, tanto pelo histórico domínio das soluções proprietárias, quanto pela aparente insegurança gerada pela idéia de uma tecnologia independente de uma grande corporação. No entanto, à medida em que o Linux vai ficando mais estável e vai sendo mais utilizado, estes temores vão diminuindo e cada vez parece haver mais adeptos e defensores do uso de software livre. Nesse contexto, vale ressaltar que, apesar dos problemas anteriormente relatados, a disseminação da cultura do uso do software livre por governos, entidades civis e empresas é de vital importância para facilitar o avanço da inclusão digital. O Linux já mostrou-se economicamente competitivo, sendo inclusive um software de qualidade superior em muitos casos por ser mais estável, e mais resistente ao ataque de vírus.

${ }^{43}$ Existem algumas extensões de arquivos que são compatíveis, mas geralmente resumem-se aos programas básicos.

${ }^{44}$ AQUISTAPASSE, C., entrevistado pela Revista do Linux. Porto Alegre dá o exemplo. Disponível em: http://www.revistadolinux.com.br/ed/038/assinantes/entrevista.php3 [Acessado em 12-03-05] 
Ainda que seja importante que cada indivíduo tenha acesso às redes de informação, seja a partir da escola, de seu local de trabalho, de sua habitação, de telecentros ou de outras instâncias, não basta facilitar o acesso a computadores e à internet: é imprescindível promover a alfabetização digital para que estes usuários tornem-se também produtores de conteúdo na rede. No Brasil e no mundo, é fato, como já foi apresentado, que quanto menor a renda e o mais baixo o nível de escolaridade, menor é o acesso à internet. Como afirma Castells (2000, p. 77-81), a possibilidade de aquisição de habilidades básicas para o uso destas tecnologias parece estar ligada diretamente ao grau de renda e de instrução, o que permite supor que o acesso a estas tecnologias poderá melhorar o padrão de vida destas pessoas. É importante capacitá-las para a utilização dessas mídias em favor dos interesses e necessidades tanto individuais como comunitários, com responsabilidade e senso de cidadania.

No próximo capítulo serão apresentadas características de algumas experiências nacionais e internacionais significativas que comprovam a capacidade dos telecentros de promover a inclusão digital e de permitir que comunidades excluídas e fragmentadas se unam em direção à sua integração social. 